Shimizu and colleagues ${ }^{1}$ have demonstrated that both VPI and tumor size had a significant impact on survival for patients with NSCLC in univariate analysis. However, tumor size failed to be a predictor of survival in multivariate analysis, whereas VPI was still a significant predictor for all patients with NSCLC $(P<.001)$ and those with stage I disease $(P=.0104)$. VPI overwhelmed tumor size as a prognostic factor for NSCLC in their study. However, most studies in the literature have reported tumor size as a significant prognostic factor in NSCLC. The International Association for the Study of Lung Cancer Lung Cancer Staging Project Committee has recommended that $\mathrm{T} 1$ tumors be classified as T1a $(\leq 2 \mathrm{~cm})$ and $\mathrm{T} 1 \mathrm{~b}(>2$ to $\leq 3 \mathrm{~cm})$ and that $\mathrm{T} 2$ tumors be classified as T2a ( $>3$ to $\leq 5 \mathrm{~cm}), \mathrm{T} 2 \mathrm{~b}(>5$ to $\leq 7 \mathrm{~cm})$, and $\mathrm{T} 3$ $(>7 \mathrm{~cm}) .{ }^{5}$ However, revision of nonsize-based $\mathrm{T} 2$ descriptors has not been recommended because of the small number of patients, inconsistent clinical and pathologic results, or lack of validation. ${ }^{5}$ Their proposal emphasized the prognostic value of tumor size in NSCLC. Shimizu and colleagues ${ }^{1}$ have also demonstrated that VPI was significantly associated with tumor size. We wonder how the authors dealt with the interaction of the 2 variables in multivariate analysis and interpreted the greater effect of VPI on survival in their study.

Jung-Jyh Hung, MD ${ }^{a, b}$
Jung-Sen Liu, MD,PhD
Wen-Hu Hsu, MD
Catholic University
Taipei, Taiwan
${ }^{a}$ Cathay General Hospital and Fu Jen
Taipei Veterans General Hospital
Taipei, Taiwan
and National Yang-Ming University
References
1. Shimizu K, Yoshida J, Nagai K, Nishimura M, Ishii G,
Morishita Y, et al. Visceral pleural invasion is an inva-
sive and aggressive indicator of non-small cell lung
cancer. J Thorac Cardiovasc Surg. 2005;130:160-5.
2. Mountain CF. Revisions in the international system
for staging lung cancer. Chest. 1997;111:1710-7.
3. Martini N, Bains MS, Burt ME, Zakowski MF,
McCormack P, Rusch VW, et al. Incidence of local

recurrence and second primary tumors in resected stage I lung cancer. J Thorac Cardiovasc Surg. 1995;109:120-9.

4. López-Encuentra A, Gómez de la Cámara A, RamiPorta R, Duque-Medina JL, de Nicolás JL. Sayas J; Bronchogenic Carcinoma Cooperative Group of the Spanish Society of Pneumology and Thoracic Surgery (GCCB-S). Previous tumour as a prognostic factor in stage I non-small cell lung cancer. Thorax. 2007;62:386-90.

5. Rami-Porta R, Ball D, Crowley J, Giroux DJ, Jett J, Travis WD, et al. The IASLC Lung Cancer Staging Project: proposals for the revision of the T descriptors in the forthcoming (seventh) edition of the TNM classification for lung cancer. $J$ Thorac Oncol. 2007;2:593-602.

doi:10.1016/j.jtcvs.2008.12.053

\section{SERUM BRAIN NATRIURETIC PEPTIDE FOR PREDICTION OF SUCCESSFUL MEDICAL TREATMENT OF PATENT DUCTUS ARTERIOSUS IN PREMATURE INFANTS \\ To the Editor:}

We read with great interest the report by Tschuppert and colleagues ${ }^{1}$ entitled "The Effect of Ductal Diameter on Surgical and Medical Closure of Patent Ductus Arteriosus in Preterm Neonates: Size Matters" and the relevant letter by Giardini and colleagues. ${ }^{2}$

Although Tschuppert and colleagues suggested that the size of a patent ductus arteriosus (PDA) can be used to predict patients in whom medical management is likely to fail to achieve hemodynamic irrelevance, Giardini and colleagues claimed that the difference in PDA diameter in patients who did and did not respond to medical treatment was extremely low and questioned how such a small difference can be clinically significant. ${ }^{2}$

We would like to add some comment regarding factors other than PDA size to predict successful medical treatment according to our pilot study.

Recent reports suggesting that serum brain natriuretic peptide (sBNP) levels are parallel to the severity of $\mathrm{PDA}^{3-5}$ prompted us to investigate the relationship between the dose of indomethacin and the levels of sBNP or maximum diameter of PDA by ultrasound cardiography (USCG) during the first week of life. Indomethacin was repeatedly (1-4 times) administered intravenously at a single dose of 0.1 to $0.2 \mathrm{mg} / \mathrm{kg}$ until the closure of the PDA was confirmed by USCG. sBNP was measured by a commercially available kit using fluorescent immunoassay ("Shiono-Spot," Shionogi Pharmaceutical Co, Osaka, Japan). The required blood volume is only $70 \mu \mathrm{L}$, and a result can be obtained within 15 minutes with this kit.

There was a significant relationship between the peak levels of sBNP within 5 days of life and the total dose of indomethacin $(\mathrm{n}=8, r=$ $0.78, P<.05$, Table). Notably, the required total dose of indomethacin to close a symptomatic PDA was 0.1 to $0.2 \mathrm{mg} / \mathrm{kg}$ in the infants with sBNP levels less than $1000 \mathrm{pg} / \mathrm{mL}$, whereas the required dose was $0.3 \mathrm{mg} / \mathrm{kg}$ or more in those with higher sBNP levels $(>2000 \mathrm{pg} / \mathrm{mL})$, as shown in Table 1 .

TABLE 1. Relationship among serum levels of brain natriuretic peptide, size of patent ductus arteriosus, and total dose of indomethacin

\begin{tabular}{lccccc}
\hline Case no. & $\begin{array}{c}\text { Gestational } \\
\text { age (wk) }\end{array}$ & $\begin{array}{c}\text { Total dose of } \\
\text { indomethacin } \mathbf{( m g} / \mathbf{k g})\end{array}$ & $\begin{array}{c}\text { Age at PDA } \\
\text { closure* (d) }\end{array}$ & $\begin{array}{c}\text { Peak levels } \dagger \text { of } \\
\text { sBNP }(\mathbf{p g} / \mathbf{m L})\end{array}$ & $\begin{array}{c}\text { Maximum } \\
\text { diameter of } \\
\text { PDA (mm) }\end{array}$ \\
\hline 1 & 27.7 & 0.1 & 5 & 640.4 & 1.5 \\
2 & 27.7 & 0.2 & 8 & 40.9 & 1.2 \\
3 & 31.4 & 0.2 & 3 & 83.2 & 1.4 \\
4 & 28.0 & 0.2 & 3 & 796.5 & 1.5 \\
5 & 28.7 & 0.2 & 3 & 152.3 & 2.1 \\
6 & 28.7 & 0.3 & 16 & $>2000$ & 2.1 \\
7 & 29.9 & 0.6 & 5 & $>2000$ & 3.9 \\
$8 \ddagger$ & 29.9 & 0.7 & 14 & $>2000$ & 3.3 \\
\hline
\end{tabular}

$P D A$, Patent ductus arteriosus; $s B N P$, serum brain natriuretic peptide. $*$ Confirmed by ultrasound echocardiography. $\dagger$ Measured within 5 days of life. $\ddagger$ PDA reopened at the age of 16 days and received surgical ligation. 
Furthermore, closure of the PDA occurred within 10 days in all of 5 infants demonstrating lower levels of sBNP $(<1000 \mathrm{pg} / \mathrm{mL})$, whereas closure occurred in only 1 of 3 infants with higher levels $(>2000 \mathrm{pg} / \mathrm{mL})$ : One infant who required the largest dose of indomethacin finally required operative ligation for the PDA because it reopened (case number 8 in Table 1).

From these findings, we suggest that the hemodynamic severity of the PDA in addition to the size of the PDA should be taken into consideration to predict the possibility of successful medical treatment and to seek the timing of surgical intervention because no single parameter can be a complete index. The measurement of sBNP in the early postnatal days can be adjunctive and useful for these purposes because it is rather objective than the measurement of PDA diameter by USCG and requires only a small blood sample.

Atsushi Ohashi, MD

Kazunari Kaneko, PhD, MD

Department of Pediatrics Kansai Medical University Osaka, Japan

\section{References}

1. Tschuppert S, Doell C, Arlettaz-Mieth $\mathrm{R}$ Baenziger O, Rousson V, Balmer C, et al. The effect of ductal diameter on surgical and medical closure of patent ductus arteriosus in preterm neonates: size matters. J Thorac Cardiovasc Surg. 2008;135: $78-82$.

2. Giardini A, Derrick G. The effect of ductal diameter on surgical and medical closure of patent ductus arteriosus in preterm neonates. $J$ Thorac Cardiovasc Surg. 2008;136:240.

3. Sanjeev S, Pettersen M, Lua J, Thomas R, Shankaran S, L'Ecuyer T. Role of plasma B-type natriuretic peptide in screening for hemodynamically significant patent ductus arteriosus in preterm neonates. J Perinatol. 2005;25:709-13.

4. Choi BM, Lee KH, Eun BL, Yoo KH, Hong YS Son CS, et al. Utility of rapid B-type natriuretic peptide assay for diagnosis of symptomatic patent ductus arteriosus in preterm infants. Pediatrics. 2005;115:255-61.
5. Puddy VF, Amirmansour C, Williams AF, Singer DR. Plasma brain natriuretic peptide as a predictor of haemodynamically significant patent ductus arteriosus in preterm infants. Clin Sci. 2002; 103:75-7.

doi:10.1016/j.jtcvs.2008.09.083

\section{MECHANISM OF MYOCARDIAL PROTECTION BY PRESSURE-VOLUME UNLOADING INVOLVES STRETCH-INDUCED PATHOPHYSIOLOGY}

\section{To the Editor:}

I read with interest the recent report by Tamareille and colleagues, ${ }^{1}$ who demonstrate in a porcine model of myocardial infarction that left ventricular (LV) unloading with a left ventricular assist device (LVAD) during early reperfusion is associated with both reduced endothelin-1 release by the myocardium and reduced infarct size. They demonstrate a positive correlation between early post-ischemia endothelin release and infarct size but admit that a cause-effect relationship was not established by this study. They found no effect of LV unloading on regional myocardial blood flow. Our laboratory previously demonstrated that LV unloading during early reperfusion ameliorates myocardial stunning in a canine model of regional ischemiareperfusion. ${ }^{2}$ As did Tamareille and colleagues, we found no differences in regional myocardial blood flow between LVAD-treated and untreated animals. By using ultrasonic dimension crystals, however, we observed marked ischemia-induced segmental stretch during both systole (paradoxical bulging) and diastole (creep), phenomena that were completely eliminated by LV pressure-volume unloading. We hypothesized that LVAD- mediated alleviation of abnormal stretch was responsible for improved contractile function. We later tested this hypothesis in an isolated guinea pig papillary muscle model, ${ }^{3}$ in which we demonstrated that abnormal stretch caused contractile dysfunction similar to stunning. This dysfunction was abolished by gadolinium, a lanthanide cation that blocks a variety of stretchinduced perturbations in cardiac function through mechanisms that may involve specific stretch-activated ion channels. We then returned to the canine model and demonstrated that gadolinium attenuates regional stunning to the extent of mechanical LV unloading. ${ }^{4}$ I would therefore suggest to the authors that the mechanism of infarct reduction with $L V$ unloading observed in their study was not reduced endothelin release, but the elimination of abnormal stretch, which also happened to reduce endothelin release.

Alfred C. Nicolosi, MD Division of Cardiothoracic Surgery Medical College of Wisconsin Milwaukee, Wis

\section{References}

1. Tamareille S, Achour H, Amirian J, Felli P, Bick RJ, Poindexter B, et al. Left ventricular unloading before reperfusion reduces endothelin-1 release and calcium overload in porcine myocardial infarction. $J$ Thorac Cardiovasc Surg. 2008;136:343-51.

2. Nicolosi AC, Markley JG, Olinger GN. Effects of postischemic left ventricular pressure-volume unloading on contractile recovery and myocardial blood flow in the regionally stunned canine heart. J Thorac Cardiovasc Surg. 1999;118:181-8.

3. Nicolosi AC, Kwok CS, Contney SJ, Olinger GN, Bosnjak ZJ. Gadolinium prevents stretch-mediated contractile dysfunction in isolated papillary muscles. Am J Physiol Heart Circ Physiol. 2001;280: H1122-8.

4. Nicolosi AC, West G, Markley JG, Logan B, Olinger GN. Gadolinium attenuates regional stunning in the canine heart in vivo. $J$ Thorac Cardiovasc Surg. 2002;124:57-62.

doi:10.1016/j.jtcvs.2008.09.084 